\title{
PENGARUH KONDISI KEUANGAN PERUSAHAAN TERHADAP TINGKAT PENGEMBALIAN SAHAM PADA PERUSAHAAN MANUFAKTUR YANG TERDAFTAR DALAM BURSA EFEK INDONESIA
}

\author{
Paryanto, N. Dicky Sumarsoso \\ Sekolah Tinggi Ilmu Ekonomi AAS Surakarta \\ Email : paryanto.stieaas@gmail
}

\begin{abstract}
Abstrak : Penelitian ini bertujuan untuk mengetahui pengaruh variabel price book value, price earning ratio, earning per share dan deviden pay out ratio terhadap tingkat pengembalian saham (return saham) pada perusahaan manufaktur yang listing di BEI periode 2014-2016.

Dalam penelitian ini, peneliti menggunakan purposive sampling dan memperoleh sampel sebesar 72 sampel. Dari sampel yang diperoleh tersebut, penulis menggunakan uji regresi linier berganda untuk menjelaskan hubungan antar variabel tersebut. Hasilnya menyebutkan $18,2 \%$ tingkat pengembalian saham (return saham) dipengaruhi oleh price book value, price earning ratio, earning per share dan deviden pay out ratio, sisanya $81,8 \%$ dipengaruhi oleh variabel lain.

Pengujian secara parsial berhasil membuktikan price book value, earning per share dan deviden pay out ratio berpengaruh signifikan terhadap return saham, sedangkan price earning ratio tidak berpengaruh signifikan tehadap return saham. Sedangkan pengujian secara simultan menunjukkan price book value, price earning ratio, earning per share dan deviden pay out ratio mempunyai pengaruh yang signifikan terhadap return saham.
\end{abstract}

Kata kunci: price book value, earning per share deviden pay out ratio return saham.

\begin{abstract}
This study aims to determine the effect of variable price book value, price earnings ratio, earnings per share and dividend pay out ratio on stock returns (stock returns) on manufacturing companies listing on the IDX for the 2014-2016 period.

In this study, researchers used purposive sampling and obtained a sample of 72 samples. From the sample obtained, the writer uses multiple linear regression test to explain the relationship between these variables. The result stated that $18.2 \%$ of stock returns (stock returns) were influenced by price book value, price earnings ratio, earnings per share and dividend pay out ratio, the remaining $81.8 \%$ was influenced by other variables.

Partial testing succeeded in proving price book value, earning per share and dividend pay out ratio had a significant effect on stock returns, while price earning ratio did not significantly influence stock returns. While testing simultaneously shows price book value, price earnings ratio, earnings per share and dividend pay out ratio has a significant effect on stock returns.
\end{abstract}

Keywords: price book value, earnings per dividend share pay out ratio stock return. 


\section{PENDAHULUAN}

Investor sebelum melakukan investasi pada perusahaan yang terdaftar di BEI melakukan analisis kondisi/kinerja perusahaan antara lain menggunakan rasio keuangan yang berkaitan dengan return perusahaan (Husnan, 2003 :44). Kondisi/kinerja keuangan akan menentukan tinggi rendahnya harga saham di pasar modal. Apabila kondisi keuangan perusahaan menunjukkan adanya prospek yang baik, maka sahamnya akan diminati investor dan harganya meningkat. Dengan meningkatnya harga saham tentunya return saham yang diterima investor juga meningkat. Dari berbagai rasio keuangan terdapat beberapa rasio dan informasi keuangan perusahaan yang dapat digunakan untuk memprediksi return saham. Dalam penelitian ini penulis menggunakan 5 rasio keuangan sebagai variabel bebas penelitian, yakni : price book value, price earning ratio, earning per share dan deviden pay out ratio. Variabel- variabel tersebut merupakan rasio-rasio keuangan untuk mengukur kondisi keuangan perusahaan dalam rangka membuat keputusan berinvestasi saham jangka panjang.

Seorang investor dalam melakukan investasi saham akan berharap untuk mendapatkan imbalan berupa laba atau peningkatan nilai ekonomi saham. Investor tidak tertarik dengan saham yang memiliki return negatif dan rendah karena akan menurunkan kesejahteraan investor.

Dalam memperkirakan tingkat pengembalian (rate of return) yang akan didapat, investor terlebih dahulu akan melakukan penelitian terhadap kondisi/kinerja perusahaan.

Kondisi keuangan akan menentukan tinggi rendahnya harga saham dipasar modal. Berarti return saham juga ditentukan oleh kondisi/kinerja keuangan perusahaan. Apabila kondisi/kinerja keuangan perusahaan menunjukkan adanya prospek yang baik, maka sahamnya akan diminati investor dan harganya meningkat (Harianto dan Sudomo, 2001). Dengan meningkatnya harga saham tentunya return saham yang diterima investor juga meningkat. Untuk itu investor perlu melakukan pengukuran kondisi/kinerja keuangan perusahaan.

Ukuran umum yang digunakan para investor dalam menilai kondisi keuangan perusahaan adalah analisis rasio keuangan. Dari berbagai rasio keuangan terdapat beberapa rasio dan informasi keuangan perusahaan yang didapat digunakan untuk memprediksi return saham. Rasio keuangan yang dapat dipakai untuk memprediksi return saham dalam penelitian ini adalah price book value, price earning ratio, earning per share dan deviden pay out ratio.

Rasio yang menggambarkan seberapa besar pasar menghargai nilai buku saham suatu perusahaan adalah Price to Book Value $(P B V)$. Price to book value yang tinggi mencerminkan tingkat kemakmuran para pemegang saham, dimana kemakmuran bagi pemegang saham merupakan tujuan utama dari perusahaan. Semakin rendah rasio ini akan memberikan gambaran bahwa semakin trendahnyanya harga saham perusahaan, menunjukkan semakin buruknya kinerja perusahaan, sehingga dapat memberikan tingkat return yang lebih menurun di masa yang akan datang.

Rasio yang digunakan untuk mengukur jumlah uang yang dibayarkan oleh penanam modal untuk setiap rupiah pendapatan perusahaan adalah Price Earning Ratio (PER). Semakan rendah Price Earning Ratio (PER) perusahaan berarti saham perusahaan tidak dapat memberikan return yang besar bagi investor, semakin rendah kepercayaan investor terhadap masa depan perusahaan atas pemberian hasil investasi. Price Earning Ratio (PER) 
digunakan oleh para investor untuk memprediksi kemampuan perusahaan dalam menghasilkan laba di masa yang akan datang. Investor dapat mempertimbangkan rasio ini untuk memilah-milah saham mana yang nantinya dapat memberikan keuntungan yang besar dimasa mendatang. PER menunjukkan hubungan antara harga pasar saham biasa dengan earning per share. Tingkat keuntungan yang tinggi menandakan pertumbuhan perusahaan dari masa mendatang. Perusahaan dengan peluang tingkat pertumbuhan yang rendah biasanya mempunyai PER yang rendah, demikian pula sebaliknya perusahaan dengan pertumbuhan yang tinggi memiliki $P E R$ yang tinggi. PER merupakan bagian dari rasio pasar dari sudut pandang investor dan juga merupakan ukuran untuk menentukan bagaimana pasar memberi harga pada saham suatu perusahaan.

Jumlah keuntungan yang diperoleh untuk setiap lembar saham biasa disebut dengan Earning Per Share (EPS). EPS yang rendah menandakan bahwa perusahaan tersebut tidak mampu memberikan tingkat kesejahteraan yang lebih baik kepada pemegang saham dan sebaliknya. Dengan demikian EPS menunjukkan kemampuan perusahaan dalam mendapatkan laba dan mendistribusikan laba yang diperoleh perusahaan kepada pemegang saham.

Dividen payout ratio (DPR) merupakan Perbandingan antara dividen yang dibayarkan dengan dengan laba yang tersedia untuk pemegang saham umum (Hartono, 1998). Investor cenderung tidak menyukai perusahaan yang memiliki tingkat $D P R$ yang rendah karena dianggap tidak mampu memberikan keuntungan yang lebih baik dengan tingkat kepastian yang lebih baik.

Mengingat dalam membuat keputusan berinvestasi dalam saham memerlukan analisi kondisi keuangan perusahaan dan mengingat pentingnya return saham yang tinggi untuk meningkatkan kepercayaan investor dalam menanamkan modalnya dalam suatu perusahaan maka peneliti tertarik untuk meneliti faktor-faktor yang mempengaruhi tingkat pengembalian saham (return saham) perusahaan dengan judul: Pengaruh Kondisi Keuangan Terhadap Return Saham Pada Perusahaan Manufaktur Yang Terdaftar Dalam Bursa Efek Indonesia Tahun 2014 -2016.

\section{KERANGKA TEORITIS DAN PENGEMBANGAN HIPOTESIS}

\section{Pengaruh Price to Book Value (PBV) terhadap return saham}

Keberadaan price book value sangat penting bagi investor untuk menentukan strategi investasi di pasar modal karena melalui price to book value, investor dapat memprediksi saham-saham yang overvalued atau undervalued (Ahmed dan Nanda, 2004). Price to Book Value $(P B V)$ merupakan rasio perbandingan antara harga saham dan nilai buku per saham dari suatu perusahaan. Rasio ini menggambarkan seberapa besar pasar menghargai nilai buku saham suatu perusahaan. Semakin tinggi rasio ini akan memberikan gambaran bahwa semakin tingginya harga saham perusahaan menunjukkan semakin baiknya kinerja perusahaan, sehingga dapat memberikan tingkat return yang lebih baik di masa yang akan datang.

Dari penjelasan tersebut maka dapat ditarik hipotesis yang pertama sebagai berikut: 
$\mathrm{H}_{1}=$ Price Book Value berpengaruh signifikan terhadap return saham pada perusahaan manufaktur yang terdaftar dalam Bursa Efek Indonesia Tahun 2014 -2016.

\section{Pengaruh Price Earning Ratio (PER) terhadap return saham}

Price earning ratio bermanfaat untuk melihat bagaimana pasar menghargai kinerja saham suatu perusahaan terhadap kinerja perusahaan yang tercermin dalam laba per saham. Menurut Brigham dan Houston (2010:150), Price Earning Ratio adalah: Rasio harga per saham terhadap laba per saham menunjukkan jumlah yang rela dibayarkan oleh investor untuk setiap dolar laba yang dilaporkan. PER yang tinggi menunjukkan bahwa investor bersedia untuk membayar dengan harga saham premium untuk perusahaan. Berdasarkan pendapat di atas pengertian $P E R$ yang dimaksud dalam penelitian ini adalah rasio yang membandingkan antara harga saham per lembar saham biasa yang beredar dengan laba per lembar saham.

Dari penjelasan tersebut maka dapat ditarik hipotesis yang kedua sebagai berikut:

$\mathrm{H}_{2}=$ Price Earning Ratio berpengaruh signifikan terhadap return saham pada perusahaan manufaktur yang terdaftar Dalam Bursa Efek Indonesia Tahun 2014 -2016.

\section{Pengaruh Earning Per Share (EPS) terhadap return saham}

Earning Per Share (EPS) digunakan untuk mengukur presentase laba terhadap harga saham. Laba per lembar saham merupakan jumlah keuntungan yang diperoleh untuk setiap lembar saham biasa. EPS yang tinggi menandakan bahwa perusahaan tersebut mampu memberikan tingkat kesejahteraan yang lebih baik kepada pemegang saham. Dengan demikian EPS menunjukkan kemampuan perusahaan dalam memperoleh laba dan mendistribusikan laba yang diraih perusahaan kepada pemegang saham.

Dari penjelasan tersebut maka dapat ditarik hipotesis yang ketiga sebagai berikut:

$\mathrm{H}_{3}=$ Earning Per Share berpengaruh signifikan terhadap Return Saham Pada Perusahaan Manufaktur Yang Terdaftar Dalam Bursa Efek Indonesia Tahun 2014 -2016

\section{Pengaruh Dividen payout ratio (DPR) terhadap return saham}

Rasio pembayaran diveden (dividend payout ratio) menentukan jumlah laba yang dapat ditahan sebagai sumber perdanaan. Semakin besar laba ditahan semakin sedikit jumlah laba yang dialokasikan untuk pembayaran dividen. Menurut Van Home dkk (2009:475), rasio pembayaran dividen adalah persentase laba yang dibayarkan dalam bentuk dividen dengan total laba yang tersedia bagi pemegang saham. Jika perusahaan memotong dividen maka akan dianggap sebagai sinyal yang buruk karena dianggap perusahaan membutuhkan dana. Oleh karena itu perusahaan yang memiliki risiko tinggi cenderung memiliki DPR yang lebih kecil supaya nanti tidak memotong dividen jika laba yang diperoleh turun.Untuk perusahaan yang berisiko tinggi, probabilitas untuk mengalami laba yang menurun lebih tinggi, akibatnya investor cenderung menghindari sahamnya. Hal ini berbeda dengan kondisi perusahaan yang memiliki tingkat $D P R$ yang tinggi, investor cenderung menyukai perusahaan ini karena dianggap mampu memberikan keuntungan yang lebih baik dengan tingkat kepastian yang lebih baik.

Dari penjelasan tersebut maka dapat ditarik hipotesis yang keempat sebagai berikut: $\mathrm{H}_{4}=$ Deviden Pay Out berpengaruh positif terhadap Return Saham Pada Perusahaan Manufaktur Yang Terdaftar Dalam Bursa Efek Indonesia Tahun 2014 -2016. 
Pengaruh Price Book Value, Price Earning Ratio, Earning Per Share Dan Deviden Pay Out Ratio secara bersama-sama terhadap return saham pada perusahaan manufaktur yang terdaftar dalam Bursa Efek Indonesia Tahun 2014 -2016

Dalam memperkirakan tingkat pengembalian (rate of return) yang akan didapat, investor terlebih dahulu perlu melakukan pengukuran kondisi/kinerja keuangan perusahaan. Kondisi/kinerja keuangan akan menentukan tinggi rendahnya harga saham di pasar modal. Apabila kondisi/kinerja keuangan perusahaan menunjukkan adanya prospek yang baik, maka sahamnya akan diminati investor dan harganya meningkat. Dengan meningkatnya harga saham tentunya return saham yang diterima investor juga meningkat.

Teknik analisis yang digunakan untuk mengukur kinerja keuangan perusahaan dalam rangka untuk membuat keputusan investasi saham jangka panjang adalah analisis fundamental, yang merupakan teknik analisis yang menitik beratkan pada rasio keuangan.

Menurut Husnan (2009:307) analisis fundamental memprediksi harga saham di masa yang akan datang dengan cara mengestimasi faktor-faktor fundamental yang mempengaruhi harga saham dimasa yang akan datang dan menghubungkan variabel-variabel sehingga diketahui perkiraan harga saham. Yang mana dalam penelitian ini penulis menggunakan 5 variabel, yakni Price Book Value, Price Earning Ratio, Earning Per Share dan Deviden Pay Out Ratio. Variabel- variabel tersebut merupakan rasio-rasio keuangan untuk mengukur kondisi/kinerja keuangan perusahaan dalam rangka membuat keputusan berinvestasi saham jangka panjang.

Dari penjelasan tersebut maka dapat ditarik hipotesis yang kelima sebagai berikut: H5 = Price Book Value, Price Earning Ratio, Earning Per Share Dan Deviden Pay Out Ratio secara bersama-sama berpengaruh terhadap Return Saham Pada Perusahaan Manufaktur Yang Terdaftar Dalam Bursa Efek Indonesia Tahun 2014 -2016.

Kerangka penelitian ini dapat digambarkan sebagai berikut :

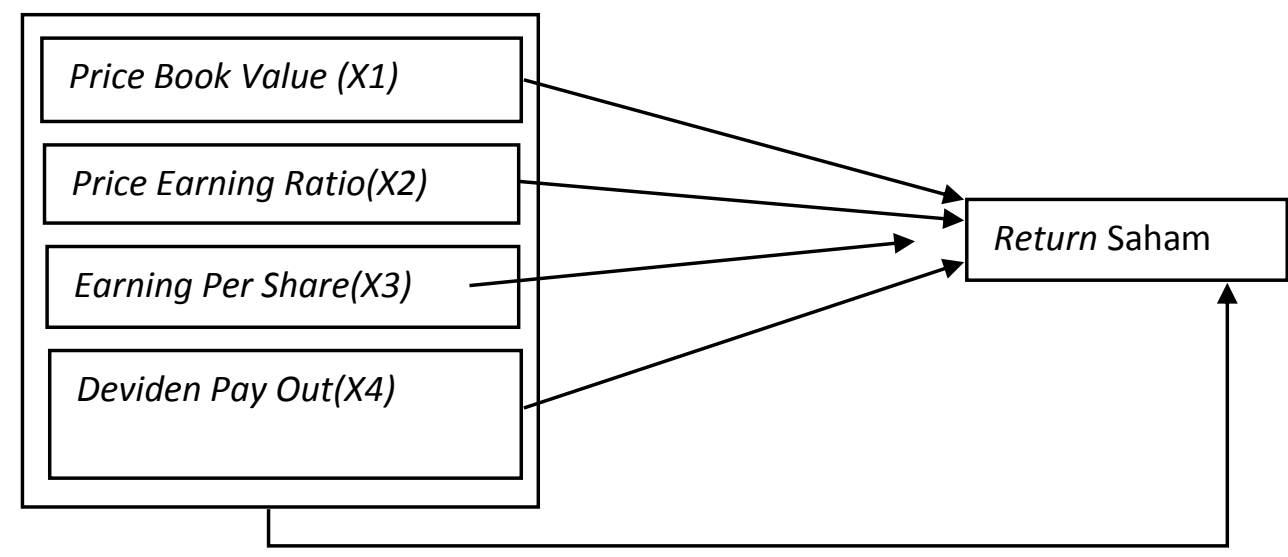

Gambar 1. Kerangka Pemikiran

\section{METODE PENELITIAN}

Data yang diperlukan dari penelitian ini terdiri dari Laporan Keuangan Tahunan (Annual Report) yang diterbitkan oleh perusahaan yang menjadi objek penelitian. 
Populasi yang digunakan untuk penelitian ini adalah seluruh perusahaan yang terdaftar di Bursa Efek Indonesia (BEI). Teknik penentuan sampel dalam penelitian ini adalah dengan menggunakan purposive sampling. Terdapat beberapa kriteria perusahaan yang terdaftar dalam Bursa Efek Indonesia periode 2014-2016 untuk dapat menjadi sampel dalam penelitian.

\section{VARIABEL PENELITIAN}

\section{Variabel Dependen (Y)}

\section{Return saham}

Return saham merupakan salah satu faktor yang mendorong para investor berinvestor berinvestasi danmerupakan imbalan atas keberanian investor menanggung resiko atas investasi yang dilakukannya.Rumus Menghitung Return Saham sebagai berikut :

Return saham $=\frac{\mathrm{P} 1-\mathrm{P} 0}{\mathrm{P} 0} \quad$ (Brigham dan Houston, 2006: 410)

Keterangan:

$P t$ atau $P 1=$ Price, yaitu harga untuk waktu $\mathrm{t}$

$P t-1$ atau $P 0=$ Price, yaitu harga untuk waktu sebelumnya

\section{Variabel Independen $(\mathbf{X})$}

\section{Price Book Value (X1)}

Price to Book Value $(P B V)$ merupakan rasio perbandingan antara harga saham dan nilai buku per saham dari suatu perusahaan.

$P B V=\frac{\text { Harga per lembar saham }}{\text { nilai buku per lembar saham }}$

\section{Price Earning Ratio $\left(\mathbf{X}_{2}\right)$}

Price earning ratio adalah rasio yang menggambarkan perbandingan antara harga saham terhadap earning perusahaan (Tandelilin,2010). Secara matematis rumus untuk menghitung PER (price earning ratio ) adalah :

Price Earning Ratio $=\frac{\text { Harga Per Lembar Saham }}{\text { Pendapatan Per Lembar Saham }}$

\section{Earning Per Share / Laba Per Lembar Saham $\left(\mathbf{X}_{3}\right)$}

Tandelilin (2001:241) mendefinisikan Earning Per Share (EPS) sebagai perbandingan antara jumlah laba (dalam hal ini laba bersih yang siap dibagikan bagi pemegang saham) dengan jumlah saham yang beredar.

Laba Per Saham $=\frac{\text { Laba Bersih }}{\text { Jumlah Saham Beredar }}$ Brigham dan Houston (2006: 19)

\section{Deviden Payout Ratio $\left(\mathrm{X}_{4}\right)$}

Menurut Van Home dkk (2009:475), rasio pembayaran dividen adalah persentase laba yang dibayarkan dalam bentuk dividen dengan total laba yang tersedia bagi pemegang saham. Rasio pembayaran diveden (dividend payout ratio) menentukan jumlah laba yang dapat ditahan sebagai sumber perdanaan.

$$
D P R=\frac{\text { Deviden per Lembar Saham }}{\text { Laba per Lembar Saham }} \times 100 \%
$$




\section{HASIL DAN PEMBAHASAN}

\section{Tabel 1. Hasil Analisis Deskriptif Data}

Descriptive Statistics

\begin{tabular}{|l|r|r|r|r|r|}
\hline & N & Minimum & Maximum & \multicolumn{1}{c|}{ Mean } & $\begin{array}{c}\text { Std. } \\
\text { Deviation }\end{array}$ \\
\hline Y & 78 & -.817 & 1.793 & .14267 & .583169 \\
X1 & 78 & -.310 & 12.650 & 1.40936 & 2.108456 \\
X2 & 78 & -278.930 & 485.360 & 31.61827 & 84.575316 \\
X3 & 78 & -8.970 & 813.840 & 108.47227 & 176.226046 \\
X4 & 78 & .000 & 80.760 & 11.12038 & 19.512892 \\
Valid N (listwise) & 78 & & & & \\
\hline
\end{tabular}

Sumber : Data sekunder yang diolah, 2018.

Berdasarkan hasil statistik deskriptif dari masing-masing variabel :

Jumlah total nilai variabel Return saham paling rendah yang dicapai perusahaan sebesar 0,817 total nilai variabel Return Saham paling tinggi yang dicapai perusahaan sebesar 1,793. Secara keseluruhan nilai rata-rata variabel Return Saham sebesar -0,14267 dengan deviasi standar sebesar 0,583169.

Jumlah total nilai variabel Price Book Value paling rendah yang dicapai perusahaan sebesar 0,310 total nilai variabel Price Book Value paling tinggi yang dicapai perusahaan sebesar 12,650. Secara keseluruhan nilai rata-rata variabel Price Book Value sebesar 1,40936 dengan deviasi standar sebesar 2,108456

Jumlah total nilai variabel Price Earning Ratio paling rendah yang dicapai perusahaan sebesar -278,930 total nilai variabel Price Earning Ratio paling tinggi yang dicapai perusahaan sebesar 485,360. Secara keseluruhan nilai rata-rata variabel Price Earning Ratio sebesar 31,61827 dengan deviasi standar sebesar 84,575316

Jumlah total nilai variabel Earning Per Share paling rendah yang dicapai perusahaan sebesar $-8,970$ total nilai variabel Earning Per Share paling tinggi yang dicapai perusahaan sebesar 813,840. Secara keseluruhan nilai rata-rata variabel Earning Per Share sebesar 108,47227 dengan deviasi standar sebesar 176,226046.

Jumlah total nilai variabel Deviden Payout Ratio paling rendah yang dicapai perusahaan sebesar 0,000 total nilai variabel Deviden Payout Ratio paling tinggi yang dicapai perusahaan sebesar 80,760. Secara keseluruhan nilai rata-rata variabel Deviden Payout Ratio sebesar 11,12038 dengan deviasi standar sebesar 19,512892.

\section{Analisis Regresi Linier Berganda}

Berdasarkan hasil perhitungan SPSS yang nampak di tabel 2 di bawah ini persamaan regresi sebagai berikut:

$\mathrm{Y}=0,039+0,079 P B V-0,001 P E R+0,001 E P S-0,009 D P R+\mathrm{e}$. 
Dari persamaan regresi tersebut di dapat diketahui bahwa variabel bebas yang berpengaruh positif terhadap return saham perusahaan adalah Price Book Value dengan koefisien sebesar 0,079 dan Earning Per Share dengan koefisien 0,001. Hal ini berarti bila Price Book Value, dan Earning Per Share meningkat maka return saham perusahaan meningkat pula. Sedangkan variabel bebas yang berpengaruh negatif terhadap return saham perusahaan adalah Price Earning Ratio dengan koefisien 0,001 dan Deviden Payout Ratio dengan koefisien 0,009. Hal ini berarti bila Price Earning Ratio dan Deviden Payout Ratio menurun maka return saham perusahaan meningkat dan sebaliknya.

Tabel 2

Rangkuman Hasil Uji Hipotesis

\begin{tabular}{|c|c|c|c|c|}
\hline Variabel & $\mathrm{b}$ & $\mathrm{t}_{\text {hitung }}$ & Sig & Kesimpulan \\
\hline Konstans & 0,039 & & & \\
$\mathrm{X} 1$ & 0,079 & 2,668 & 0,010 & Berpengaruh Signifikan \\
$\mathrm{X} 2$ & $-0,001$ & $-1,486$ & 0,142 & Tidak Berpengaruh Signifikan \\
$\mathrm{X} 3$ & 0,001 & 2,507 & 0,015 & Berpengaruh Signifikan \\
$\mathrm{X} 4$ & $-0,009$ & $-2,704$ & 0,009 & Berpengaruh Signifikan \\
& & & & Berpengaruh Signifikan \\
\hline F $_{\text {hitung }}$ & 4,940 & 0,001 & 0,182 \\
\hline Adjusted $\mathrm{R}^{2}$ & & \multicolumn{3}{l}{} \\
\hline
\end{tabular}

Sumber : data sekunder diolah, 2018

\section{Uji Signifikan Parameter Individual (Uji -t Statistik)}

Uji t digunakan untuk mengetahui signifikansi secara parsial dari variabel independent yaitu: Price Book Value $\left(\mathrm{X}_{1}\right)$, Price Earning Rati o $\left(\mathrm{X}_{2}\right)$, Earning Per Share $\left(\mathrm{X}_{3}\right)$ dan Deviden Payout Ratio $\left(\mathrm{X}_{4}\right)$ terhadap variabel dependent yaitu: Return saham perusahaan (Y).

Dari table 4.5 di atas diketahui besarnya pengaruh masing-masing variabel independen terhadap variabel dependen adalah sebagai berikut :

Signifikasi t untuk variabel Price Book Value sebesar 0.010 lebih kecil dari $\alpha(0,05)$. Hal ini berarti berarti Price Book Value secara parsiil berpengaruh signifikan terhadap return saham perusahaan.

Signifikasi t untuk variabel Price Earning Ratio sebesar 0,142 lebih besar dari $\alpha(0,05)$. Hal ini berarti Price Earning Ratio tidak berpengaruh signifikan terhadap return saham perusahaan .

Signifikasi t untuk variabel Earning Per Share sebesar 0,015 lebih kecil dari $\alpha(0,05)$. Hal ini berarti Earning Per Share berpengaruh signifikan terhadap return saham perusahaan.

Signifikasi t untuk variabel Deviden Payout Ratio sebesar 0,009 lebih kecil dari $\alpha$ $(0,05)$. Hal ini berarti Deviden Payout Ratio berpengaruh signifikan terhadap return saham perusahaan .

\section{Uji Signifikansi Simultan (uji statistik F)}

Dari hasil perhitungan statistik menggunakan SPSS yang nampak di tabel 2 diperoleh nilai $\mathrm{F}$ hitung sebesar 4,940 dengan tingkat signifikansi 0,001. Nilai signifikansi $\mathrm{F}$ yang dihasilkan tersebut lebih kecil dari $\alpha .=0,05$. Hal ini berarti bahwa variabel Price Book Value, Price Earning Ratio, Earning Per Share, dan variabel Deviden Payout Ratio secara simultan berpengaruh signifikan terhadap variabel return saham perusahaan. 


\section{Uji Koefisien Determinasi (uji statistik $\boldsymbol{R}^{2}$ )}

Dari hasil perhitungan dengan program SPSS yang nampak di tabel 2 dapat diketahui bahwa koefisien determinasi yang dapat dilihat dari Adjusted $R$ Square, diperoleh sebesar 0,182 . Hal ini berarti hanya $18,2 \%$ return saham perusahaan dapat dijelaskan oleh variabel Price Book Value, Price Earning Ratio, Earning Per Share dan Deviden Pay Out Ratio dalam penelitian ini, sedang sisanya $81,8 \%$ dijelaskan oleh variabel lain yang tidak diteliti dalam penelitian ini.

\section{PEMBAHASAN HASIL PENELITIAN}

\section{Pengaruh Price Book Value terhadap return saham perusahaan}

Berdasarkan pada uji signifikansi parameter individual, diperoleh kesimpulan bahwa Price Book Value secara parsiil berpengaruh signifikan terhadap return saham perusahaan dengan tingkat signifikansi sebesar 0.010 lebih kecil dari $\alpha(0,05)$. Hasil penelitian ini bisa diasumsikan pasar menghargai nilai buku saham perusahaan manufaktur yang terdaftar di Bursa Efek Indonesia tahun 2014-2016 yang berarti pula kepercayaan pasar terhadap prospek perusahaan kedepan juga tinggi. Sehingga para investor mengambil keputusan berinvestasi di perusahaan manufaktur yang terdaftar di Bursa Efek Indonesia tahun 2014-2016. Dengan makin banyaknya perusahaan yang berinvestasi di perusahaan manufaktur maka semakin tinggi juga harga sahamnya. Semakin tinggi harga saham maka akan semakin tinggi juga return sahamnya. Hasil penelitian ini tidak sejalan dengan penelitian yang dilakukan Nesa Anisa yang menyatakan Price Book Value tidak berpengaruh signifikan terhadap return saham perusahaan pada perusahaan manufaktur yang terdaftar di Bursa Efek Indonesia.

\section{Pengaruh Price Earning Ratio terhadap return saham perusahaan}

Berdasarkan pada uji signifikansi parameter individual, diperoleh kesimpulan bahwa Price Earning Ratio tidak berpengaruh signifikan terhadap return saham perusahaan dengan tingkat signifikasi sebesar 0,142 lebih besar dari $\alpha(0,05)$. Hal ini bisa diasumsikan walaupun Price Earning Ratio perusahaan manufaktur yang tergabung dalam Bursa Efek Indonesia tahun 2014-2016 meningkat tetapi tidak diikuti dengan meningkatnya kepercayaan investor terhadap masa depan perusahaan sehingga tidak memicu peningkatan harga saham perusahaan manufaktur yang terdaftar di Bursa Efek Indonesia tahun 2014-2015. Jadi apabila harga per lembar saham tidak meningkat/menurun dan tingkat pertumbuhan laba suatu perusahaan juga tidak meningkat, maka Price Earning Ratio juga menurun dan return saham juga akan menurun. Hasil penelitian ini sejalan dengan penelitian yang dilakukan Nesa Annisa yang menyatakan Price Earning Ratio (PER) tidak berpengaruh terhadap Return saham perusahaan manufaktur yang terdaftar di Bursa Efek Indonesia periode 2008 - 2011. Hasil penelitian ini juga sejalan dengan penelitian yang dilakukan Suriani Ginting yang menyatakan Price Earning Ratio (PER) tidak berpengaruh terhadap Return saham perusahaan manufaktur yang terdaftar di Bursa Efek Indonesia periode 2008 - 2011. Hasil penelitian ini juga sejalan dengan penelitian yang dilakukan Farda Eka Septiana yang menyatakan Price Earning Ratio tidak berpengaruh signifikan terhadap return saham pada perusahaan manufaktur sektor food and baverage yang terdapat di BEI periode 2009-2014. 


\section{Pengaruh Earning Per Share terhadap return saham perusahaan}

Berdasarkan pada uji signifikansi parameter individual, diperoleh kesimpulan bahwa Earning Per Share berpengaruh signifikan terhadap return saham perusahaan dengan tingkat signifikasi sebesar 0,015 lebih kecil dari $\alpha(0,05)$. Hasil penelitian ini bisa diasumsikan tingkat keuntungan per lembar saham perusahaan manufaktur yang terdaftar di Bursa Efek Indonesia tahun 2014-2016 relatif besar, sehingga meningkatkan minat investor untuk menanamkan sahamnya pada sektor manufaktur. Hasil penelitian ini tidak sejalan dengan penelitian yang dilakukan oleh Desy Arista yang menyatakan Earning Per Share (EPS) tidak berpengaruh signifikan terhadap return saham perusahaan manufaktur yang terdaftar di Bursa Efek Indonesia. Hasil penelitian ini juga tidak sejalan dengan penelitian yang dilakukan oleh Jullie Sondakh, Winston Pontoh, dan Steven Tangkuman yang menyatakan Earning Per Share (EPS) tidak berpengaruh signifikan terhadap return saham perusahaan manufaktur yang terdaftar di Bursa Efek Indonesia selama tahun 2006-2010.

\section{Pengaruh Deviden Pay Out Ratio terhadap return saham perusahaan}

Berdasarkan pada uji signifikansi parameter individual, diperoleh kesimpulan Deviden Payout Ratio berpengaruh signifikan terhadap return saham perusahaan dengan tingkat signifikasi sebesar 0,009 lebih kecil dari $\alpha(0,05)$. Hasil penelitian ini bisa diasumsikan bahwa semakin tinggi nilai $D P R$ perusahaan manufaktur yang daftar di Bursa Efek Indonesia berdampak pada meningkatnya nilai saham, berkaitan dengan hal ini para investor akan mendapatkan kepastian mengenai adanya pembagian dividen yang lebih baik atas investasinya. Hal ini mampu meningkatkan permintaan atas saham tersebut, 6sehingga berdampak pada meningkatnya harga saham, serta berimbas pada return yang positif. Hasil penelitian ini sejalan dengan penelitian yang dilakukan oleh Riawan yang menyatakan kebijakan dividen (DPR) berpengaruh signifikan terhadap tingkat pengembalian saham di perusahaan tergabung dalam Islamic Index Jakarta yang terdaftar di Bursa Efek Indonesia untuk periode 2010-2013. Hasil penelitian ini juga sejalan dengan penelitian yang dilakukan oleh Michael Aldo Carloyang menyatakan DPR berpengaruh positif dan signifikan pada return saham di perusahaan yang terdaftar dalam indeks LQ45 tahun 2010-2012.

\section{Perusahaan Secara Simultan Price Book Value, Price Earning Ratio, Earning Per Share dan Deviden Pay Out Ratio Terhadap Kondisi Keuangan Perusahaan}

Hasil penelitian ini menunjukkan bahwa Price Book Value, Price Earning Ratio, Earning Per Share dan Deviden Pay Out Ratio secara simultan berpengaruh signifikan terhadap kondisi/kinerja keuangan perusahaan dengan tingkat signifikansi sebesar $0,001<\alpha=$ 0,05. Artinya apabila semakin besar pasar menghargai nilai buku saham perusahaan (Price Book Value semakin tinggi), semakin tinggi jumlah yang rela dibayarkan oleh investor untuk setiap dolar laba yang dilaporkan (Price Earning Ratio semakin tinggi), semakin tinggi kemampuan perusahaan dalam memperoleh laba dan mendistribusikan laba yang diraih perusahaan kepada pemegang saham (Earning Per Share semakin tinggi) dan semakin besar laba ditahan semakin sedikit jumlah laba yang dialokasikan untuk pembayaran dividen (semakin tinggi dividend payout ratio) maka return saham perusahaan semakin besar pula. 


\section{KESIMPULAN}

Berdasarkan hasil penelitian dan pembahasan tentang pengaruh pengaruh kondisi keuangan perusahaan terhadap tingkat pengembalian (return) saham pada perusahaan manufaktur yang terdaftar dalam Bursa Efek Indonesia tahun 2014-2016, maka dapat diambil beberapa kesimpulan dari penelitian ini sebagai berikut :

Price Book Value berpengaruh positif dan signifikan terhadap return saham perusahaan-perusahaan manufaktur yang terdaftar di Bursa Efek Indonesia tahun 2014-2016. Hal ini menunjukkan pasar menghargai nilai buku saham perusahaan manufaktur yang terdaftar di Bursa Efek Indonesia tahun 2014-2016 yang berarti pula kepercayaan pasar terhadap prospek perusahaan kedepan juga tinggi. Sehingga para investor mengambil keputusan berinvestasi di perusahaan manufaktur yang terdaftar di Bursa Efek Indonesia tahun 2014-2016. Dengan makin banyaknya perusahaan yang berinvestasi di perusahaan manufaktur maka semakin tinggi juga harga sahamnya. Semakin tinggi harga saham maka akan semakin tinggi juga return sahamnya.

Price Earning Ratio berpengaruh negatif, tidak signifikan terhadap return saham perusahaan-perusahaan manufaktur yang terdaftar di Bursa Efek Indonesia tahun 2014-2016. Hal ini menunjukkan bahwa Price Earning Ratio perusahaan manufaktur yang tergabung dalam Bursa Efek Indonesia tahun 2014-2016 meningkat tetapi tidak diikuti dengan meningkatnya kepercayaan investor terhadap masa depan perusahaan sehingga tidak memicu peningkatan harga saham perusahaan manufaktur yang terdaftar di Bursa Efek Indonesia tahun 2014-2016. Jadi apabila harga per lembar saham tidak meningkat/menurun dan tingkat pertumbuhan laba perusahaan juga tidak meningkat, maka Price Earning Ratio juga menurun dan return saham juga akan menurun.

Earning Per Share berpengaruh positif signifikan terhadap return saham perusahaanperusahaan manufaktur yang terdaftar di Bursa Efek Indonesia tahun 2014-2016. Ini dapat diartikan tingkat keuntungan per lembar saham perusahaan manufaktur yang terdaftar di Bursa Efek Indonesia tahun 2014-2016 meningkat, sehingga meningkatkan minat investor untuk menanamkan sahamnya pada perusahaan manufaktur yang terdaftar di Bursa Efek Indonesia tahun 2014-2016. Meningkatnya minat investor untuk menanamkan sahamnya di perusahaan mengakibatkan meningkatnya harga saham dan selanjutnya diikuti dengan meningkatnya return saham perusahaan.

Deviden Pay Out Ratio berpengaruh negatif signifikan terhadap return saham perusahaan-perusahaan manufaktur yang terdaftar di Bursa Efek Indonesia tahun 2014-2016. Hasil penelitian ini bisa diasumsikan dengan meningkatnya Deviden Payout Ratio perusahaan manufaktur yang daftar di Bursa Efek Indonesia tahun 2014-2016 tidak serta-merta kepercayaan investor meningkat pula. Meningkatnya $D P R$ perusahaan tidak diikuti pada meningkatnya permintaan atas saham perusahaan, sehingga harga saham tidak meningkat pula, serta berimbas pula pada tidak meningkatnya return saham perusahaan manufaktur yang daftar di Bursa Efek Indonesia tahun 2014-2016.

Price Book Value, Price Earning Ratio, Earning Per Share, dan variabel Deviden Payout Ratio secara simultan berpengaruh signifikan terhadap return saham perusahaan.

Return saham perusahaan dapat dijelaskan oleh variabel Price Book Value, Price Earning Ratio, Earning Per Share dan Deviden Pay Out Ratio hanya sebesar 18,2\%, sedang sisanya $81,8 \%$ dijelaskan oleh variabel lain yang tidak diteliti dalam penelitian ini. 


\section{DAFTAR PUSTAKA}

Ahmed dan Nanda. 2004. Style Investing: Incorporating PBV in Value Stocks. The Journal of Portofolio Management

Anoraga, pandji dan Piji Pakarti. 2008. Pengantar Pasar Modal. Cetakan 3. Jakarta: Rineka Cipta.

Anto Dajan. 2000. Pengantar Metode Statistik. Jilid I, II, Jakarta: LP3ES.

Basuki, Sulistyo. 2006. Metode Penelitian. Jakarta: Wedatama Widya Sastra.

Brigham dan Houston. 2010. Dasar-dasar Manajemen Keuangan Buku 1. Edisi 11. Jakarta : Salemba Empat.

Desy Arista. Analisis Faktor - Faktor Yang Mempengaruhi Return Saham (Kasus Pada Perusahaan Manufaktur Yang Go Public Di Bei Periode Tahun 2005 - 2009). Jurnal Ilmu Manajemen dan Akuntansi Terapan. Vol 3. Nomor 1. Mei 2012.

Farda Eka Septiana. Pengaruh Rasio Keuangan Terhadap Return Saham Pada Perusahaan Manufaktur. Jurnal Ilmu dan Riset Manajemen: Volume 5. Nomor 1. Januari 2016.

Ginting, Suriani. Analisis Faktor-Faltor Yang Mempengaruhi Return Saham Pada Perusahaan Manufaktur Yang Terdaftar Di Bursa Efek Indonesia. Jurnal Wira Ekonomi Mikroskil. Volume 3. Nomor 01. April 2013.

Ghozali, Imam. 2011. Aplikasi Analisis Multivariate Dengan Program SPSS. Semarang: Badan Penerbit Universitas Diponegoro.

Gujarati, D., 1991. Basic Econometrics. Terjemahan Sumamo Zain. Jakarta: Erlangga.

Halim, Abdul dan Mamduh M. Hanafi. 2009. Analisis Laporan Keuangan. Edisi 4. Yogyakarta: UPP STIM YKPN.

Hartono, Jogiyanto. 2008. Teori Portofolio Dan Analisis Investasi. Yogyakarta:BPFE.

Horne James C. Van dan John M.Wachowicz. 2009. Prinsip - Prinsip Manajemen Keuangan. alih bahasa Dewi Fitriasari dan Deny A.Kwary. Jakarta: Salemba.

Jullie Sondakh, Winston Pontoh, dan Steven Tangkuman. Pengaruh Rasio Keuangan Atas Return Saham Pada Perusahaan Industri Manufaktur Di Bursa Efek Indonesia. Jurnal LPPM Bidang EkoSosBudKum. Volume 1. Nomor 1. Tahun 2014

Michael Aldo Carlo. Pengaruh Return On Equity, Dividend Payout Ratio, Dan Price To Earnings Ratio Pada Return Saham. E-Jurnal Akuntansi. Universitas Udayana 7.1 2014.

Nawawi,Hadari. 2012. Metode Penelitian Bidang Sosial. Yogyakarta: Gajah. Mada University Press.

Nesa Anisa. Analisis Faktor-Faktor Yang Mempengaruhi Return Saham (Studi Kasus Pada Perusahaan Sub Sektor Automotive And Components Yang Terdaftar Di Bursa Efek Indonesia Periode 2010-2014). Perbanas Review. Volume 1. Nomor 1. November 2015 .

Riawan. Peran Profitabilitas Dan Likuiditas Serta Dividen Payout Ratio Terhadap Return Saham. Media Trend. Vol. 11 No. 2 Oktober 2016. 
Paryanto, dkk./ Edunomika Vol. 02 No. 02 (Agustus 2018)

Tandelilin, Eduardus. 2010. Portofolio dan Investasi Teori dan Aplikasi. Edisi. Pertama. Yogyakarta: Kanisius IKAPI.

UmaSekaran. 2006. Metodologi Penelitian untuk Bisnis. Edisi 4. Buku 1, Jakarta: Salemba Empat.

Usman, Husaini. 2003. Metodologi Penelitian Sosial. Jakarta: Bumi Aksara. 